\title{
A review on scientific technologies in practice to innovate plant based molecules and to improve herbal drug quality to overcome health problems
}

\author{
K.K. Gupta*1, G. Khandelwal ${ }^{1}$, G. Prasad ${ }^{1}$,A.K. Chopra ${ }^{2}$ and A. Mishra ${ }^{1}$ \\ ${ }^{1}$ Department of Botany and Microbiology, Gurukula Kangri University, Haridwar-249404 (Uttarakhand), INDIA \\ ${ }^{2}$ Department of Zoology and Environment Science, Gurukula Kangri University, Haridwar-249404 (Uttarakhand), INDIA \\ *Corresponding author.E-mail: kartikey77@ rediffmail.com
}

\begin{abstract}
Medicines obtained from drug plants and other sources are commonly called traditional medicines. They have played an important role in the treatment of several human diseases since ancient times. India possessed a great wealth of traditional health care system known as Ayurveda related to the use of plant species. The global market of herbal drugs has a great potential around the world. Demand of plant based medicines is also increasing among western countries because of a general consideration that most allopathic drugs are associated with more or less side effects. Many pharmaceutical companies are now manufacturing Ayurvedic phytopharmaceutical products. However, enough efforts have not been made to get suitable substitute of modern allopathic medicines from these traditionally used drug plants and herbal drugs. This traditional system of healthcare in India still needs extensive evidence-based scientific researches in promoting its therapies. This review paper deals with modern scientific approaches to find out new plant based molecules and to develop new technologies in a continuous process and should be applied in the practice to improve the quality of herbal drugs in Indian pharmaceutical industries. Critical assessment of quality assurance including researches on pharmacognosy, chemistry, pharmacology, antimicrobial activity and clinical studies carried out on various Ayurvedic medicinal plants are also being presented.
\end{abstract}

Keywords: Scientific technologies, Plant based molecules, Herbal drug, Health

\section{INTRODUCTION}

Diseases and death of human beings has been a natural phenomenon since the evolution of humans on earth. They have always made an effort to keep them healthy and disease free by using different substances distributed in the nature around them. Plants being earlier than man on the planet are not only the source of food and shelter but also have become a powerful source of remedies for a large number of human diseases. According to World Health Organization (WHO, 1978), "a medicinal plant is any plant which, in one or more of its organs, contains substances that can be used for therapeutic purposes, or which are precursors for chemopharmaceutical semi-synthesis". The traditional systems of medicine are still considered as a great knowledge based in herbal medicines (Singh and Lal, 2008). The medicinal plants have regained a wide recognition to combat infectious diseases due to the failure of modern drugs against various chronic diseases along with increasing costs and side effects associated with them. Emergence of multi-drug resistant strains of pathogenic bacteria and higher safety margins also contribute towards increasing interest in traditional medicine. Phytochemicals have contributed significantly to the development of new drugs from medicinal plants (Cox,

1990; Veale et al., 1992; Eisenberg et al., 1993; Cox and Balick, 1994; Prance, 1994; Samy, et al., 2008). Ethnobotanical studies have also brought to light numerous plants having significant medicinal properties which were earlier unknown to scientific world (Pushpangadan et al., 1988; Kaul et al., 1989; Subramaniam et al., 1997, 1999). For instance, revealing cardiac effect of the leaves of Digitalis purpurea that were useful for treating dropsy is the best example of folk use based herbal medicine (Cox, 1994). Patenting of Jeevani, a drug from Arogyapaacha plant (Trichopus zeylanicus spp. travancoricus) is another latest example of drug, which could be developed from traditional medicine based leads (Butani et al., 1994; Pushpangadan et al., 1996; and Singh and Lal, 2008).

Researches to find out scientific evidence for claims of plants being used for traditional system of medicines have been intensified for the last few years. It is estimated that only less than $10 \%$ of 250,000 flowering plants in the world have been examined successfully for their potential medicines and still $90 \%$ remains to be explored. It is a matter of great concern that around 60,000 species of higher plants may probably become extinct by the year 2050 (Yogeeswaran, 2003). This creates a sense of urgency with regard to priority for preservation of 
medicinal plants. Therefore, the traditional knowledge along with its holistic and systematic approach supported by experimental data can serve as an innovative and powerful discovery engine for newer, safer and affordable medicines in future (Samy et al., 2008). The prime objective of the review is to discuss the current status of herbal drugs in the management of human health care in present times.

\section{HERBAL DRUG SCENARIO ININDIA}

Plant products have been used to treat human diseases since ancient times in different forms such as grinded powder, poultice, decoction (ashava and arista) etc. But India has been among leading countries of the world in utilizing plant kingdom for human disease management. India has a large number of geographical zones providing rich diversity of plant species, that has resulted in the development of many systems of herbal medicine. Vedas are considered as first documented record of human knowledge conserving almost every aspect of the life. Rigveda (4500-1600 B.C.) an old repository of human knowledge describes 67 drug plants of great medicinal value. India has a glorious past where fully developed medical science was available before (3000-7000 B.C.) with full description of disease symptoms, pharmacogenesis and treatment. Ancient Indian Rishis have given a first documented record in sanskrit scripts in the form of Samhita. Two Samhitas namely Charak Samhita (1000-800 BC) by Maharshi Charak and Shushrut Samhita (800-700 BC) by Maharshi Shashurut are the base line of Indian Medicine System. Maharshi Charak mentioned about 500 drug plants out of which, around 300 plants are now being used in the herbal pharmaceutical industries in India. Ayurveda, an important Indian medicine system, gives a detailed description of about 700-800 herbs (Samy et al., 2008). Other traditional medicinal sys-tems of India also employs a large number of plant species e.g. Sid-dha (1121 spp.), Unani (751 spp.) and Tibetan (337 spp.) Anonymous, 2004a).

Herbal drugs constitute a major share among all the officially recognized systems of healthcare in India such as Ayurveda, Yoga, Unani, Siddha, Homeopathy and Naturopathy. These systems have rightfully existed sideby-side with Allopathy and are not in 'the domain of obscurity' (Vaidya and Devasagayam, 2007; Subramanian et al., 2003). These systems are not folklore or traditional herbal practices, but are basic axioms that serves as a determinant of therapy (Vaidya, 1992; and Vaidya and Devasagayam, 2007). A majority of medicines are being prepared from the plants products in India with major Pharmaceutical industries producing excellent herbal drug preparations in both forms i.e., nutraceutical and therapeutics. Some of the important Herbal Pharma industries actively engaged in herbal preparations can be quoted as, Gurukula Kangri Pharmacy (Haridwar), Dabur, Himalaya, Charak, Hamdard, Baidyanath, Zandu etc. There is a vast literature on Ayurveda available in different languages i.e., Hindi, Sanskrit and several regional languages along with English. Some of the recommended literatures are Indian herbal pharmacopoeia (Handa, 1998,1999); Medicinal plants of India (Satyavati et al., 1976); and clinically useful drugs (Agrawal et al., 2005). There are many references to Indian medicinal plants and spices in a number of historical documents. For instance, Indian Aloe is very widely used for cosmetic, medicinal and nutraceutical purpose in India (Srivastava and Singh, 1996). Despite the global reputation of Aloe in dermatocosmetics, the potential as antiaging is still untapped (Raina, 1996). Similarly, the plant Adhatoda vasica has been extensively studied for cough (Shah and Chauhan, 1996) but its role in the bleeding disorders and tuberculosis still needs significant research.Indian medicinal plants are also a vast source of antioxidants (Vaidya and Devasagayam, 2007). There are ayurvedic formulations containing ingredients from medicinal plants with antioxidant activities. Some of these are Amrita bindu, Centalaplus, Chapparal, Geriforte, Jigrine, Liv52, Ophtacare, P55A, Sandhika and Tamra bhasma. Recently Singh and Lal (2008) carried out ethnobotanical survey in 130 localities of Lahaul-Spiti region in Western himalaya and reported several plants used by the native traditional practitioners in herbal formulations as a remedy to cure rheumatism, liver and stomach disorders, and various sexual ailments. These include Aconitum heterophyllum (root and leaf; stomach disorders), Aconitum rotundifolium (root; liver disorders and rheumatism), Aphragmus oxycarpus (aerial parts; sexual dysfunction), Artemisia maritime (root and seed; stomach disorders and rheumatism), Bupleurum falcatum (aerial parts; stomach disorders), Capparis spinosa (shoot and flower; liver disorder and sexual dysfunction), Carum carvi (seed; sexual dysfunction and liver disorder), Crepis flexuosa (whole part; liver disorder), Ephedra regeliana (leaf and fruit; rheumatism), Erigeron borealis (leaf; stomach disorder), Gentiana moorcroftiana (aerial part; liver disorder), Gentianopsis detonsa (leaf and flower; liver disorder), Geranium pretense (whole part; liver and stomach disorder), Heracleum lanatum (root and leaf; stomach disorder and rheumatism), Hippophae tibetana (flower; sexual dysfunction and liver disorder), Lactuca rapunculoides (leaf; stomach disorder), Lepidium latifolium (leaf and flower; rheumatism), Plantago major (seed; stomach disorder), Polygonum tortuosum (aerial part; liver and stomach disorders), Rosa webbiana (flower; sexual dysfunction and liver disorders), and Scorzonera divaricata (leaf and shoot; stomach and liver disorders). 
There are still a large number of plants and Ayurvedic formulations whose activities need to be examined in relation to their potential therapeutic and related beneficial properties.

World Health organization has estimated that present demand of medicinal plants is around US\$ 14 billion per year and the projected demand by the year 2050 would be US\$ 5 trillion. Medicinal plants related trade in India is estimated to be around Rs. 550 crores per year (Anonymous, 2004b). In the US\$ 60 billion world trade in medicinal plants, India's total contribution is just around US\$ 100 million (Dubey et al., 2008). The export of herbal medicines from India is of US\$80 million. About $80 \%$ of the exports from India to developed countries constitute crude drugs instead of finished formulations resulting in low revenue for the country. The medicinal plants exported from India are Aconitum species (root), Acorus calamus (rhizome), Adatoda vasica (whole plant), Berberis aristata (root), Cassia augustifolia (leaf and pod), Colchicum luteum (rhizome and seed), Hedychium spicatum (rhizome), Heradeum candicans (rhizome), Inula racemose (rhizome), Juglans regia (husk), Juniperus communis (fruit), Juniperus macropoda (fruit), Picrorhiza kurrooa (root), Plantago ovata (seed and husk), Podophyllum emodi (rhizome), Pinica granatum (flower, root and bark), Rauwolfia serpentina (root), Rheum emodi (rhizome), Saussurea lappa (rhizome), Swertia chirayita (whole plant), Valeriana jatamansi (rhizome), Zingiber officinale (rhizome). Five of these, i.e Glycerriza glabra, Commiphora mukul, Plantago ovata, Aloe barbadensis and Azardica indica are used in modern medicines. Others are used in 52 to 141 herbal formulations and Triphala (Terminalia chebula, Terminalia belerica and Embelica officinalis ) is used in 219 formulation (Shrikumar and Ravi, 2007).

The major plants used by Indian Pharmaceutical Industries are Ajwain (Carum copticum), Akkalkadha (Anacycus pyrethrum), Cardamomum green (Elettaria cardamomum), Aloes (Aloe vera), Amala green (Emblica officinalis), Anantmool (Hemidesmus indicus), Baheda (Terminalia belerica), Brahmi (Bacopa monnieri), Bhringraj (Eclipta alba), Chitrak (Plumbago zeylanica), Dalchini (Cinnamomum zeylanicum), Daruhaldi (Berberis aristata), Gajpippali (Scindapsus officiale), Guggul (Commiphora wightii), Harda (Terminalia chebula), Jambhul beej (Eugenia jambolana), Jatamansi (Nardostachys grandiflora), Jeshthimadh (Glycyrrhiza glabra), Ashwagandha (Withania somnifera), Kesar (Crocus sativa), Clove (Syzygium aromaticum), Pipramool (Piper longum), Shatavari (Asparagus racemosus), Kalmegh (Andrographis paniculata) etc. (Anonymous, 2004b). The major traditional pharma sectors include Himalaya, Zandu, Dabur, Hamdard and Maharishi etc. while, modern sector pharmaceuticals are
Ranbaxy, Lupin, Allembic and others are standardizing their herbal formulations by chromatography techniques like TLC/HPLC, Finger printing, etc and have launched new projects regarding herbal formulations (Shrikumar and Ravi, 2007).

In India, a large number of academic, industrial and government institutes are actively engaged in drug plants research i.e., Central Council for Research in Ayurveda and Siddha (CCRAS), New Delhi; Indian Council for Medical Research (ICMR), New Delhi; Central Council for Research in Unani Medicine (CCRUM), New Delhi; National Bureau of Plant Genetic Resources (NBPGR), New Delhi; National Institute of Science Communication (NISCOM), New Delhi; Regional Research Laboratory (RRL), Jammu-Tawi; National Botanical Research Institute (NBRI), Lucknow; Central Drug Research Institute (CDRI), Lucknow; Central Institute for Medicinal and Aromatic Plants (CIMAP), Lucknow; Banaras Hindu University, Varanasi, Regional Medical Research Centre (ICMR), Belgaum; Pharmaceutical Education and Research Development (PERD), Ahmedabad; Indian Medical Practitoners Co-operative Pharmacy and Stores Ltd. (IMPCOPS), Chennai; Zandu Foundation, Mumbai; Nicholas Piramal Research Centre (NPRC), Mumbai; Pharmexcil, Hyderabad; Tropical Botanical Garden \& Research Institute (TBGRI), Thiruvantpuram; Botanical Survey of India, Kolkata and Foundation for Revitalization of Local Health Traditions (FRHLT), Bangalore are working in close collaboration and have initiated sizeable efforts for the development of herbal based formulations for several chronic diseases (Patwardhan et al., 2004; and Vaidya and Devasagayam, 2007).

\section{MODERN SCIENTIFIC APPROACHES FOR IMPROVEMENT OF DRUG EFFICACY OF HERBAL DRUGSAND DRUG PLANTS (Fig. 2)}

Since last decade of $20^{\text {th }}$ century, several efforts have been made to utilize the drug plants components scientifically for getting better results in the field of medicines. It is generally believed that the standardization of herbal drugs is not required by traditional healers of rural communities for primary health care. However, the concept of good manufacturing practice for the manufacture, processing, packaging and storage of Active Pharmaceutical Ingredients (APIs) should also be applied to herbal drug/drug plants, exactly similar to that of modern medicine. The presence of different species, varieties or different plant parts should be critically controlled during the entire production process and such adulteration should be avoided.

Selection of plant for potential therapeutic interest : There are different approaches that can be used for selecting plants of potential therapeutic interest 
(Farnsworth and Bingel, 1977; Phillipson and Anderson, 1989; Vlietinck and Vanden Berghe, 1991; Kinghorn, 1994; Farnsworth, 1996; and Verpoorte, 2000). Search for the medicinal plants generally follow three main routes i.e., random, ethno (including ethnobotanical, ethnomedical and ethnopharmacological) and ecological search. The ethnobotanical, ethnomedical and ethnopharmacological approach uses information obtained from ethnobotanical survey such as the geographical distribution of the plant, its abundance, whether it is threatened or endangered, shrub/fast growing tree, easily cultivable, easily identifiable (with minimum varieties) etc. Information such as season of collection, plant parts to be used, and any reported toxicity, is also required. Plants with medicinal properties can also be selected using an ecological approach, based on Zoopharmacognosy (a variation to the ecological approach) which proposes the selection of plant species regularly ingested by animals, mostly primates for reducing pain, microbial or worm infestations (Berry et al., 1995). Specifically, there are certain differences in approaches when selecting plants for an industrial or a rural application. The rural community requires medicinal plants for their primary health care and hence focuses more on selection of plants for treatment of common diseases such as diarrhoea, malaria, pneumonia, wound infections, etc. On the other hand, pharmaceutical industry requires medicinal plants for formulation of herbal drugs for commercial gain and hence focuses more on urban problems such as metabolic disorders, chronic diseases, and multi-drug resistance among infectious pathogens. Whatever is the requirement, the selection of plant should be based on its therapeutic efficacy in terms of its effect on the causative agent or on the host.

Taxonomical information: Strict directions have been given by WHO (2000) that complete taxonomical identification is an important factor during selection as the plant species can play an important role in their biological activity. Seeds for cultivation should be verified botanically including genus, species, variety/cultivar/ chemotype and origin should be traceable. The same applies to vegetatively propagated medicinal plants also (Anonymous, 2002).

Collection of medicinal plants: The prominent mode of obtaining medicinal plants is wild harvesting (Prasad and Patnaik, 1998). Qualified individuals should be designated to identify and verify collected drug plants/herbal drugs and to supervise collectors. Collection of plants from wild must be carried out in compliance with the existing regional and national and/or national species conservation legislation. Collection methods must not damage the growth environment ensuring optimum conditions for regeneration of the medicinal plant/herbal drug harvested. Medicinal plants/herbal drugs from species that are listed as endangered (CITES, Convention on International Trade in Endangered Species of Wild Fauna and Flora) must not be collected unless the relevant competent authority has given its authorization (Anonymous, 2002). Collection of medicinal plants should not be done from places that are prone to or close to sources of contamination such as areas where high levels of pesticides or other possible contaminants are used or found e.g. roadsides, drainages, mine tailings, garbage dumps and industrial facilities which may produce toxic chemicals or active pastures that may lead to microbial contamination.

Scientific cultivation practices: The feasibility of cultivating medicinal plants would, however, depend on a number of factors such as the ability of the species on the demand and market prices. Cultivation of medicinal plants would seem as a commercially attractive option because cultivation can reduce the dependence on collection of plants from wild and thus have the potential to save wild populations and conserve their genetic diversity. Cultivation can lead to easy availability of medicinal plants with multiple uses such as those with both medicinal and commercial value. Moreover, cultivation requires intensive care and management. Introduction of non-indigenous plant species into cultivation should be avoided. The starting material (seeds/vegetatively propagated plant) should be as free as possible from diseases and pests to ensure healthy plant growth. Species resistant or tolerant to disease should preferably be used. The use of genetically modified plants or seeds must comply with regional and/or national regulation. Drug plants should not be cultivated in soil contaminated with sludge, heavy metals residues, plant protection products or other chemicals etc. Utilization of any chemicals in the growth or protection of the crop should be kept to a minimum. Manure should be thoroughly composted and free from human faeces. Other fertilizing agents may be applied sparingly and in accordance with the needs of a particular species. Fertilizers should be applied in such a manner as to minimize leaching. Irrigation should be controlled and carried out according to the needs of the medicinal plant. Water used in the irrigation should comply with regional/ national quality standards. Pesticide and herbicide applications should be avoided as far as possible, however when necessary, the minimum interval between such treatment and harvest time must be consistent with recommendations from the manufacturer of the plant protection product and regional and/or national regulation on maximum residue limits (Anonymous, 2002). Harvesting of raw drug plants materials and processing : As per guidelines (WHO, 2003), good collection practices are necessary for collection of plant materials. Proper season must be chosen for the harvesting of medicinal 
plants to ensure the best possible quality of both the starting material as well as the finished product. Seasonal variations can affect the chemical composition of the plants and thus its biological activity. In most cases, chemical constituents accumulate maximum at the flowering time and decline at the beginning of fruiting stage (Mendonca- Filho, 2006). The plant parts also play an important role in harvesting since the level of biologically active constituents can vary in different parts at different stages of plant. For example, Kursar et al. (1999) found that younger leaves of tropical rainforest plants contained secondary metabolites that were either present in very little quantities or totally absent in matured leaves. Information about plant parts that are to be used (roots, leaves, fruits, etc.) and whether these parts are seasonal or replenishable should be obtained before harvesting. Harvesting of drug plants should be done in such a manner as to avoid wet soil, dew, rain or exceptionally high air humidity. If harvesting is done under wet conditions, then possible efforts should be made to counter the adverse effects of high moisture level on drug plants/herbal drugs. Cutting devices must have minimum contamination from soil particles. Care should be taken to prevent mixing of toxic weeds with harvested plant material. Harvested plant material should not come into direct contact with the soil and should be transported under dry and clean conditions. Containers used in harvesting must be clean and free of contamination of previous harvests. Mechanical damage and compacting of harvested plant material that would produce undesirable quality changes should be avoided. There should be some measures to prevent thermal degradation of harvested material and protection from pests, mice/ rodents, livestock and domestic animals.

Processing, packaging and storage: Processing of plant materials include washing, cutting before drying, distillation etc. Prior to processing the material should not be exposed directly to the sun except wherever required. The plant materials should be protected from moisture, rains and other deterioration conditions. The inadequate means of processing make the raw material of herbal drugs prone to contamination (Dubey et al., 2008). Natural drying, i.e. drying without auxiliary energy either in the field or in sheds, should only be considered for drying of small quantities. In cases of mass production, the use of technical drying applications is indispensable. For preservation of active ingredients of plant material, comparatively low drying temperatures are recommended. The methods and temperatures used for drying have a considerable effect on the quality of raw material of the drug plant. Drying represents 30 to $50 \%$ of the total costs in medicinal plant production (Qaas and Schiele, 2001). Uniform drying of the drug plant/herbal drug is required to avoid mould formation. Drying under direct exposure to sunlight should be avoided unless specifically required. Drying conditions i.e., temperature, duration etc. should be selected according to the medicinal plant part taken such as root, leaf or flower and the nature of the active constituent for example essential oils. The source of heat in direct drying should be limited to butane, propane or natural gas. Packaging material should not cause any contamination of the product, particularly in case of fiber bags. Packaged dried medicinal plants/ herbal drugs should be stored in a dry and well-aerated building to ensure good aeration. Aerated containers are recommended during bulk transport of drug plants/ herbal drugs in order to reduce mould formation or fermentation. However, other alternatives such as sufficiently aerated transport vehicles and other aerated facilities are also advisable.

Microbiological analysis of raw drug plants and powdered herbal drugs: Raw drug plant materials are being collected from different climatic conditions and are stored in different storage conditions having different levels of temperature and humidity. Whole plant system appears prone for attack of heterogeneous groups of microorganisms which may utilize the chemical components of drug plants as food hence reduces the drug efficacy ultimately effect the drug quality. Besides this, some of them may be human pathogenic. Voluminous information regarding the presence of microorganism on raw and finished herbal industrial product is available. As far as the effect of these organism on drug efficacy is concerned only a very few fragmentary reports are available. Some of the important contribution in the field of microbial load and their effect on drug efficacy has been reported by Prasad et al. (2002a, 2003 and 2007). Considering above facts, microbiological examination of raw and finished products has also been undertaken by the researchers. But how many samples from each raw and finished drug should be taken is not described properly. This aspect is becoming more important both in maintaining drug quality and prevention of human pathogenic microorganism in the drug.

Phytochemical analysis for bioactive compounds: Internal defense mechanism system of the plants is based on enormous variety of small molecule antimicrobials. Do plants synthesize target specific antibacterials is a questions of thought. Large numbers of the plant secondary metabolites have antimicrobial activity against both Gram (+) positive and Gram (-) negative bacterial species. Phytochemical studies of the drug plant grown under different geographical conditions as well as raw herbal drug material and finish industrial products, seems very necessary and it is a demand of the time are necessary for standardization, which helps in understanding the significance of phytoconstituents in terms of their drug potency. Albeit, modern analytical 


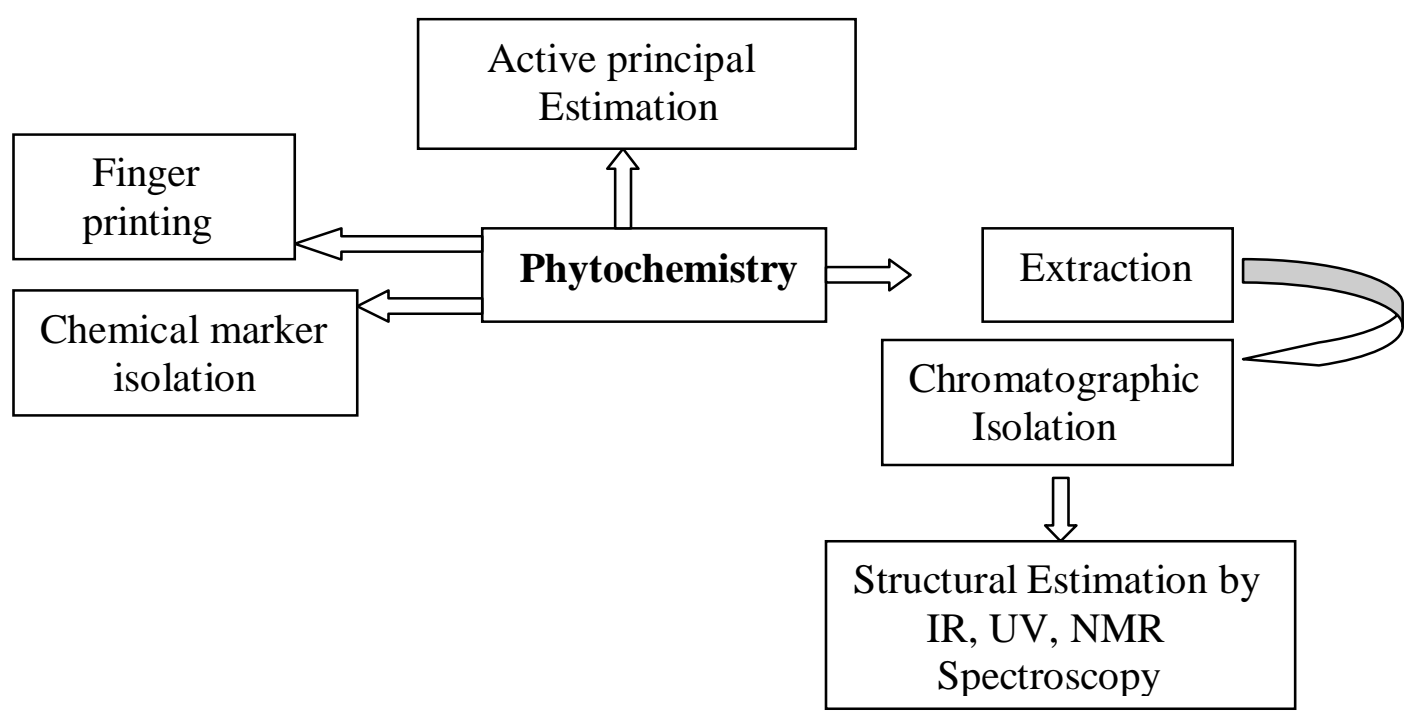

Fig.1. Steps involved in the phytochemical evaluation of herbal drugs (Ekka et al., 2008).

tools and techniques have facilitated in depth studies of medically relevant compounds contained in different plants, grown under different agroclimatic conditions. More than one lakh small molecules compounds of plant origin have been reported and a large number of among them have shown their antimicrobial nature. Some plant antimicrobials are produced at high level and owing to their mechanism of action, need to be present at milimolar concentration to offer adequate protection. since recent literature has proved the antagonistic nature of the drug plants which may be related with different compounds present in the plant system and may act collectively (synergetic) or separate individual. Therefore, it becomes an important need of evaluation of phytochemicals in both qualitative and quantitative and their standardization also becomes imperative. Therefore, currently the efforts have been made by Ethanopharmacologists, Botanist, Microbiologist and natural product chemist are combing the earth for phytochemicals and "leads" which could be developed for treatment of infectious disease (Cowan, 1999). The phytochemical standardization encompasses all the possible information generated with regard to the chemical constituents present in an herbal drug. The phytochemical evaluation for standardization purpose includes Preliminary testing for the presence of different chemical groups, Quantification of chemical groups of interest, e.g., total alkaloids, total phenolics, total triterpenic acids, total tannins, Establishment of fingerprint profiles, Multiple marker based fingerprint profiles, and Quantification of important chemical constituents.

Standardization can be carried out by obtaining a chemical fingerprint/profile or through bioactivity guided fractionation. Chemical fingerprinting techniques are the most commonly used techniques for standardization and are obtained in terms of marker compounds. A marker can be defined as a chemical entity, in the plant material which may or may not be chemically defined and serves as a characteristic fingerprint for that plant (Shrikumar and Ravi, 2007). Various analytical techniques like TLC, HPLC and HPTLC can be used to detect presence of marker compound in the plant and also to quantify it to ascertain the limits. A Biomarker on the other hand is a group of chemical compounds which are in addition to being unique for that plant material also correlate with biological efficacy (Shrikumar and Ravi, 2007). The plant extracts can also be standardized to class of compounds e.g. ginsenosides in ginseng, kava lactones in kava, or oxindole alkaloids in cat's claw (Roman, 2001). Thin layer chromatography (TLC) and HPLC are the most commonly used methods for obtaining chemical fingerprints and identification of the crude plant extracts. DNA fingerprinting is another technique, which though still in its early years, seems to be of immense potential in identification of medicinal plants, particularly when profiling the genotypic differences.

Evaluation of drug efficacy by testing the plants extracts and its pure ingredients against known pathogen by antimicrobial activity: Screening of the crude extract and isolated phytochemicals based on their antagonistic property/potency against known pathogen becomes necessary to provide a scientific basis for validating the utilization of medicinal plants. A great number of screening programs are ongoing worldwide for new plant based bioactive molecules. Several researchers have worked on medicinal plants with activity against different ailments. In recent years, the scientific evidence on the effectiveness of herbal drugs has become the focus of intense study in terms of their antimicrobial activity 
against certain microbial model in order to prove their efficacy (Amagboul et al., 1985; Artizzu et al., 1995; Izzo et al., 1995; Kubo et al., 1993; Sousa et al., 1991; Shapoval et al., 1994; Kandhansamy and Anurachalam, 2008; AlBayati, 2008; Czech et al., 2000). The emergence of MDR strains has made it difficult for clinicians to empirically select an appropriate antimicrobial agent (Walker, 2000). Therefore, in vitro antimicrobial susceptibility testing (AST) of the relevant bacterial pathogens, from properly collected specimens, should use validated methods (Anonymous, 2008). Plants extracts and phytochemicals with known antibacterial activity may be of immense importance in the therapeutic treatments (Indranil et al., 2006). There is a number of antimicrobial susceptibility testing (AST) methods available to determine bacterial susceptibility to antimicrobials. Anonymous (2008), suggested the methodology for the assessment of antimicrobial susceptibility test which are as, ease of performance, flexibility, adaptability to automated or semiautomated systems, cost, reproducibility, reliability, accuracy, the organism and the antimicrobials of interest in that particular OIE member country and availability of suitable validation data for the range of organism to be susceptibility tested.

Disc Diffusion Method and Agar Well Diffusion Method are the two most commonly used screens to determine AST (Navarro et al., 1996). The diffusion of an antimicrobial of a specified concentration from disks, tablets or strips into solid culture medium is termed as Disc Diffusion and diffusion through the holes punched in the agar medium containing culture, termed as Agar Well Diffusion, both methods mainly based on determination of an inhibition zone. Disc Diffusion is straightforward to perform, reproducible and does not require expensive equipments. Its main advantages are such as low cost, ease in modifying test antimicrobials disks when required, can be used as a screening test against large numbers of isolates, can identify a subset of isolates for further testing by other methods, such as determination of MICs.

The diffusion method is not appropriate for testing nonpolar samples or samples that do not diffuse easily into the agar. In general the relative antimicrobial potency of different samples may not always be compared mainly because of differences in physical properties such as solubility, volatility and diffusion characteristics in agar. Dilution susceptibility testing methods are used to determine MIC (Minimum Inhibitory Concentration). The test compounds are mixed with suitable medium that has previously been inoculated with the test organism. It can be carried out in liquid as well as in solid media and the growth of the microorganisms can be measured in a number of ways. In agar dilution method, the minimal inhibitory concentration (MIC) is defined as the lowest concentration able to inhibit visible microbial growth. In liquid or broth dilution methods, turbidity is most frequently used. Turbidity can be estimated visually or obtained more accurately by measuring the optical density at $405 \mathrm{~nm}$. In this case, the test samples not fully soluble may interfere with turbidity readings, thereby emphasizing the need for a negative control i.e. extract dissolved in blank medium without microorganisms. The liquid-dilution method also allows determination whether a compound or extract has cidal or static action at a particular concentration. Anonymous (2008) has described the advantages of agar dilution method which are as, the ability to test multiple bacteria, except bacteria that swarm, on the same set of agar plates at the same time, the potential to improve the identification of MIC endpoints and extend the antibiotic concentration range, and the possibility to semi-automate the method using an inoculum-replicating apparatus.

Agar dilution methods also have some disadvantages too, such as, if not automated they are very laborious, require substantial economic and technical resources, the plates prepared, normally should be used with in a week, and the endpoints are not always easy to read nor is the purity of inoculum easy to verify.

In general dilution methods are considered to be appropriate for assaying polar or non-polar extracts or compounds for determining Minimum Inhibitory concentration (MIC) and minimum Bactericidal Concentration (MBC)/ Minimum Fungicidal concentration (MFC) values (Cos et al., 2006). In past few years, a number of studies have been conducted in different countries to prove such efficacy and the thrust is still not over to find out the new source of antimicrobials of plants origin that can be used as a source of synthetic drugs in future. The effects of plant extracts have been studied by a very large number of researchers all over the world (Ates and Edrogrul, 2003; Edrogrul, 2002; and Reddy et al., 2001). Belboukhari and Cheriti (2008) reported antimicrobial effects of methanol extracts of Launeae naudiculus against Staphylococcus aureus, Escherichia coli, Pseudomonas aeruginosa, Saccharomyces cereviceae, Candida albicans. Howaida et al., (2002) have demonstrated the beneficial effects of miswak crude extracts prepared from Salvadora persica roots on oral pathogens i.e. Streptococcus mutans, Lactobacillus acidophilus, Actinobacillus actinomycetemcomitans, Actinomyces naeslundii, Porphyromonas gingivalis, Prevotella intermedia and C. albicans. Aboaba et al. (2006) demonstrated good inhibition of ethanol extracts of Entada Africana on various strains of E.coli 0157:H7 (EHEC). The antimicrobial activities of some fatty acids of Turmeric, Ginger root and Linseed was observed by Seher et al. (2006), against various gram (+) positive bacteria and 
gram (-) negative bacteria i.e. Bacillus subtilis, S. aureus, P. aeruginosa, E. coli, Klebsiella pneumoniae, Enterobacter aerogens, Streptococcus species, Proteus vulgeris, Listeria monocytogenes. They found that the extract obtained from Linseed was most potent but in general, a combination of linseed and ginger root was found to be more effective than alone. Bhattacharjee (2006), studied the antimicrobial potency of different extracts (cold and hot aqueous and ethanolic extract) of Argimone Mexicana against certain multidrug resistant bacterial species i.e. B. subtilis, $S$. aureus, $P$. aeruginosa and $E$. coli. The antibacterial activity of leaf essential oils of Eucalyptus globus and Eucalyptus camadulaensis was determined against $S$. aureus and E. coli. by Ghalem and Mohamed (2008). Abukakar et al. (2008), studied the phytochemical in crude aqueous extract of Tamarindus indica and reported that major phytochemical constituents were Saponins, Alkaloid and glycosides. Further the extracts was evaluated for their antibacterial potency against certain bacterial pathogens i.e. S. aureus, E. coli, P. aeruginosa and Salmonella typhi and extract was found effective against all the bacterial pathogens. Three strains of pathogenic bacteria (E. coli, K. pneumoniae, and $S$. aureus) were treated with condensed tannins (CT) in vitro. by Min et al. (2008). Increasing prevalence of multidrug resistant strains of microorganism has initiated the exploration of alternate antimicrobial agent. The medicinal importance of Jatropha podagrica (Hook) (Euphorbiaceae) in this respect is an attempt was made to investigate the antimicrobial potential of this plant by Bhushan et al. (2008) against S. aureus, E. coli, and C. albicans. Synergistic Activity of combination of Amoxicillin and fruit solution of Cassia fistula $(C F F)$ was studied by Ali et al. (2007) against (MDR) Salmonella enterica Serover Typhi (SEST). This novel combination is named as Amoxy-cassia. In vivo it is found to be non toxic at $1 \mathrm{gm} / \mathrm{body}$ weight of mice. Some medicinal plants used in Iran were evaluated for antibacterial properties against Bacillus cereus, Bacillus pumilus, Bordetella bronchiseptica, E. coli, K. pneumoniae, Micrococcus luteus, $P$. aeruginosa, Pseudomonas fluorescens, Serratia marcescens, $S$. aureus and Staphylococcus epidermidis by Bonjar (2004).

In vitro Antibacterial Activity of Bougainvillea spectabilis Leaves extracts were tested against $S$. aureus, B. subtilis, Streptococcus faecalis, M. luteus, E. coli, P. aeruginosa, $S$.typhii, $K$. pneumoniae, $P$. vulgaris, $S$. marcescens, Shigella flexneri and Vibrio cholera by Umamaheswari et al. (2008). In vitro Antimicrobial Activity of the extract of Mitracarpus scaber leaves which is an important ingredient of formulation of syrup, was determined against E. coli, P. aeruginosa, S. aureus, Sarcina lutea, C. albicans and K. pneumoniae by
Abere et al. (2007). They found that the growth of $E$. coli, S. aureus, K. pneumoniae and C. albicans was inhibited by the formulation at a minimum inhibitory concentration of $75 \mathrm{mg} / \mathrm{ml}$. P. aeruginosa, and S. lutea resisted all the concentrations of the formulation used. The conclusion was that the extract from the leaves of Mitracarpus scarber "Zucc" can be formulated into a pleasantly tasting oral dosage form despite its bitter taste. Bag et al. (2009) evaluated the antibacterial properties of Chebulic myrobalan (fruit of Terminalia chebula Retz.) extracts (cold aqueous, hot aqueous and ethanol) against methicillin resistant $S$. aureus and trimethoprimsulphamethoxazole resistant uropathogenic E. coli. They found that all the tested extracts showed to varying degrees of strain specific antibacterial potential against tested strains of which ethanol extract showed superior activity against $E$. coli and hot aqueous extract against $S$. aureus. Cold aqueous extract exhibited the least antibacterial activity against all the tested strains. These promising findings suggest to antibacterial activity of the plant material exhibited bioactive compounds against multi-drug resistant bacterial pathogens and serving them as an alternative antimicrobial agent against diseases caused by these organisms.

Important contribution in the area of plant as antimicrobial agent has been made by Prasad et al. (2002b; 2006; 2007). They have not only evaluated antimicrobial potency of certain drug plants against certain microorganism but they also did find out the possible application of the plant against the disease mentioned earlier in the indigenous medicine system in vitro.

Nogueira et al. (2008) studied the antimicrobial potency of extracts and oil of certain drug plants i.e. Aleolanthus suaveolens; Caryophyllus aromaticus; Cymbopogon citratus; Matricaria chamomile; Pithecellobium avaremotemo; Plectranthus amboinicus and Ruta graveolens against the pathogens which were associated with acute Otitis externa. They reported that Staphylococcus aureus, Pseudomonas aeruginosa and Candida species were frequently found. Various responses of oil was recorded against the test pathogens associated with Otitis. P. aeruginosa was resistant to all extract and oil. Growth of three strains (isolates), S aureus was inhibited at $4 \%$ and all Candida species at $01 \%$ essential oil of Caryophyllus aromaticus and Matricaria chamomile. According to them, test plants need more further detail study for significant results.

The use of plants based medicines has been increasing all over the world, not only for infectious diseases but also for other problems like cancer, high blood pressure, allergies and for general well being (Eisenberg et al., 1993). Most of the diseases like diabetes, heart diseases, cancer, psychiatric disorders, are multifactorial. Plants with 
complex phytochemical mixtures have advantage over single molecules in treating such diseases, with an added advantage of being devoid of toxic side effects. A number of such studies have been reported from all over the world including the anticoagulant properties from the seed of Cassia obtusifolia against platelet aggregation by arachidonic acid (AA), collagen, platelet activating factor (PAF), and thrombin by Jeon et al. (2009). and the anticancer effect of Dangyuja (Citrus grandis Osbeck) leaf extract was investigated using SNU-16 human gastric cancer cells by Moon et al. (2009), in which herbal remedies are used for the treatments of non-infectious diseases. The use of herbal preparations for the treatment of Alzheimer's diseases has also been reported by Neto et al. (2006).

Herbal medicines have also been used in the treatment of behavioral and psychological symptoms of Dementia (BPSD) but with various responses. Randomized controlled studies assessing AD in individuals older than 65 years were identified through searches of MEDLINE, LILACS, Cochrane Library, dissertation abstract (USA), ADEAR (Alzheimer's Disease Clinical Trials Database), National Research Register, Current Controlled trials, Centerwatch Trials Database and PsychINFO Journal Articles. The search combined the terms Alzheimer disease, dementia, cognition disorders, Herbal, Phytotherapy (Neto et al., 2006). These herbs and formulations have demonstrated good therapeutic effectiveness but these results need to be compared with those of traditional drugs (Kitula, 2007).

\section{Scientific approaches in herbal pharmaceutical}

industry: There are about 7000 firms in the small scale sector manufacturing traditional medicines with or without standardization but the authenticity, quality and purity of herbal drugs are important factors from standardization point of view and cannot be neglected. However, major traditional sector pharmas namely Himalaya, Zandu, Dabur, Charak etc are standardizing their herbal formulations by chromatography techniques and fingerprinting. The quality and purity standards are established in pharmacopoeia which prescribes structural, analytical and physical standards for the drugs (Ekka et al., 2008). Most of the drugs have definite specific chemical constituents to which their biological or pharmacological activity is attributed. Qualitative and quantitative characterization of the active ingredient should be assayed using biomarkers and the mixture should be analyzed to develop finger print profile. For isolation of compounds, chromatography techniques such as column chromatography, partition chromatography, thin layer chromatography, GLC, HPLC and HPTLC are used.

While manufacturing, the critical examination and identification of herbal drugs is required because of diversity in their chemical constituent therefore to over come this problem all the pharmacopoeia have certain standards. Drugs are manufactured from different raw materials by using different methods or process. Some impurities are incorporated into the material during the manufacturing process. In general, the possibilities of addition of impurities during the process of drug manufacturing through different manners/ways can not be ignored. These impurities added in the process may be of different in nature. Therefore a strictly guide lines prepared by Indian, indigenous pharmacopoeia must be followed. Final testing of finished product is made in the quality control laboratories. These tests are designed to determine compliance with specifications. Thus the testing of the finished product for compliance with predetermined standard prior to release of the product for packaging and subsequent distribution is a critical factor for quality assurance. This testing along with in process testing, assures that each unit contains the amount of drug claimed on the label, that all of the drug in each unit is available for complete absorption, that the drug is stable in the formulation in its specific final container closure system for its expected shelf life and that dosage units themselves contain no toxic foreign substances. The label of herbal medicine should have all the particulars required by national regulations.

Preclinical and clinical approaches: Preclinical testing helps in collection of important efficacy and safety data before clinical trials. The preclinical evaluation involves documentation and testing of pharmacological efficacy in vitro (cells) and studies of toxicology, specificity, biopharmaceutical properties and drug interactions of medicinal plants. The therapeutic effect of the plant, the efficacy and/or the mechanism of action including cell interactions, cell-environment interactions, intracellular activity, and genetic studies can be determined by preclinical studies. The advantage of these studies is that one can easily study and compare the efficacy of different plants in a cost effective manner and design rational drug combinations and it requires proper designing of screening assays. The basis for designing a screening assay is the identification of valid target. 30$40 \%$ of experimental drugs fail due to an inappropriate target (Butcher, 2003) and hence it is important to develop new screening assays with more appropriate targets. Though the cell-based assays are more challenging than with biochemical assays due to requirement of significant investments in cell culture infrastructure (Moore and Rees, 2001). The current trend is shifting towards cellbased assays because of multiple advantages, It can provide biologically more relevant information on the nature of the activity (Moore and Rees, 2001; Johnston, 2002), information regarding cellular membrane permeability and cytotoxicity. 


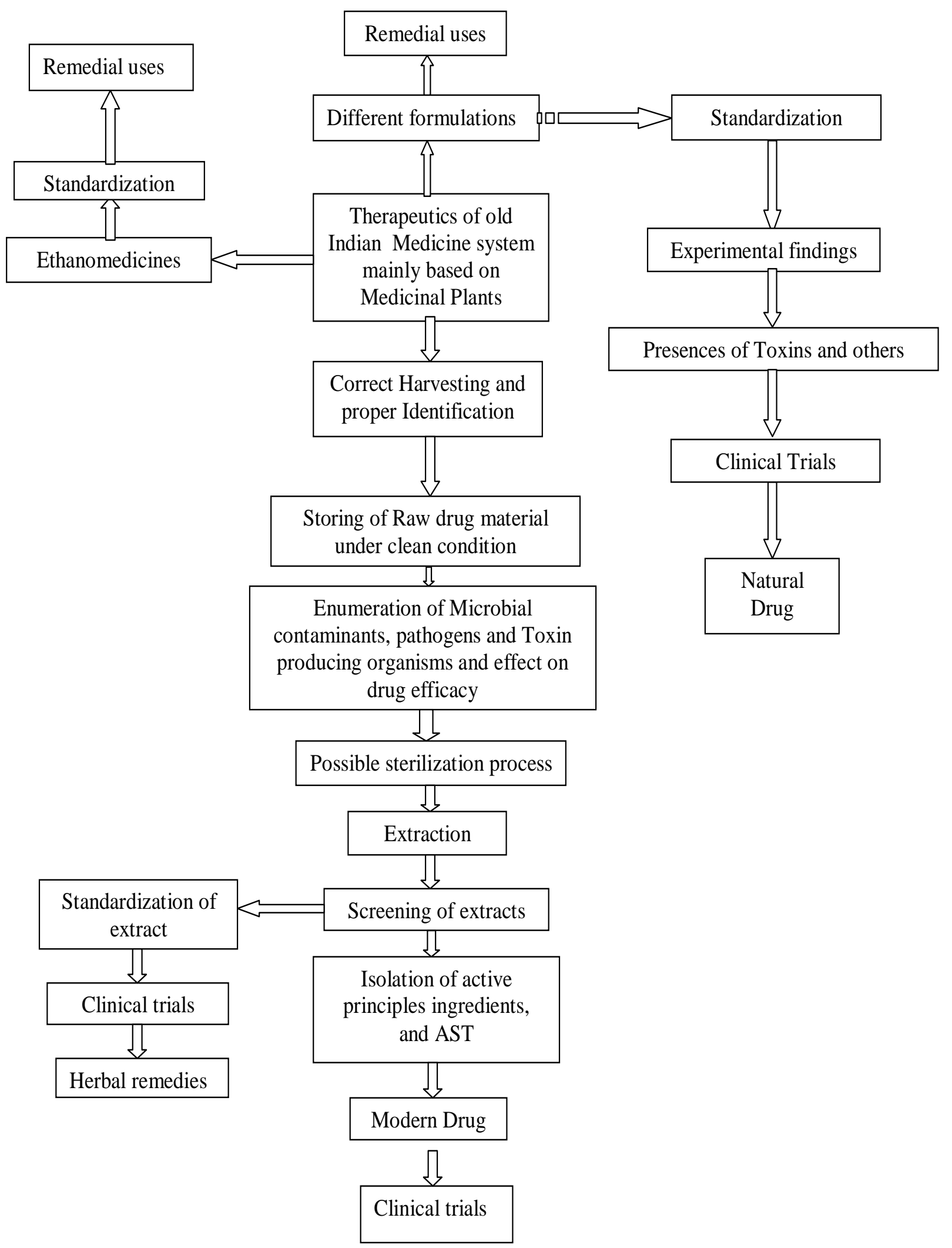

Fig. 2. Possible stages and scientific approaches for improvement of herbal drug under new drug discovery in herbal medicines. 
Approaches that are used for studying the pharmacological effects of medicinal plants are: use of single bioassay for screening multiple plants and use of multiple bioassays for studying single plant. However, this approach is not always appropriate as plants exhibit their efficacy against infectious diseases by mechanisms other than antimicrobial activity. Immunological assays and synthetic antigens are used for screening of plants for immunity-enhancing properties. There are certain limitations of preclinical studies like Suitable pharmacological models have not yet been developed for many common diseases with unknown or multifactorial origins (Hamburger and Hostettmann, 1991), Some compounds which show good activity in vitro may be metabolized in vivo into inactive metabolites. Alternatively, extracts may only show in vivo activity due to the metabolism of inactive compounds into active forms (Farnsworth, 1993), The pharmacological investigation of drug interactions in multi-compound preparations is difficult due to the presence of constituents from several plants where some plants may show less specific activity and some plants may have been added to reduce the toxicity of the more therapeutically effective plants (Taylor et al., 2001).

The pharmacological effects of medicinal plants before they can be integrated into conventional medical practice are conformed through Clinical studies. Well established, randomized controlled clinical studies facilitate the acceptance of herbal medicines in different regions. These studies should be carried out on the basis of information obtained from relevant literature or traditional medical practitioners. The principles applied for clinical studies should be followed when testing a new herbal preparation (WHO, 2000). The methods and guidelines used for clinical validation of modern medicines must be applied to herbal products even though the latter has a holistic approach to treatment. However, conventional concepts of clinical research design are difficult to apply when used to evaluate various systems and practices of traditional medicine (WHO, 2000). The reason behind the fact is that the herbal remedies are individualized therapies hence depend on the proficiency of medicinal practitioners. In some cases, Clinical studies must be adapted to deal with the specifics of herbal medicines. The number of patients required for undertaking clinical trial of medicinal plants is large and the increase in patient number also increases the time commitment and the expenses involved. Therefore only a limited number of plants can be subjected to clinical trials.

Toxicological evaluation: Toxicological evaluation of medicinal plants has been neglected since prolonged and apparently uneventful use usually is considered as a testimony of its safety. However, a history of traditional usage is not always a reliable guarantee of safety as it is difficult for traditional practitioners to monitor delayed effects (e.g. mutagenicity), rare adverse effects, and adverse effects arising from long-term use (Ernst, 1998). The use of herbal preparations may also lead to hypersensitivity reactions ranging from transient dermatitis to anaphylactic shock (Ernst, 1998). Many widely used medicinal plants have been reported as possible causes of long-term liver and kidney diseases The widespread use of Scenecio, Crotalaria and Cynoglossum has been reported in the occurrence of liver lesions and tumours, lung and kidney diseases in certain areas of Ethiopia. Therefore it becomes necessary to carry out toxicological studies, both short term and long term. Toxicological studies should include tests such as acute, subchronic and special toxicology that are impossible to detect clinically such as immunotoxicity, genotoxicity, carcinogenicity and reproductive toxicity (Remirez, 2006).

\section{DRUG PLANTS AS APOTENTTHERAPEUTIC FOR SOME CHALLENGING HUMANDISEASES}

Currently it is obvious that a large number of human diseases have not still been properly cured/managed by the modern medicines even after spending a lot of money and involvement of a large number of team workers. The efforts made in this direction could not succeed and it forced to find out some suitable substitute from the nature. Plants which have served since birth of human race on the globe has become again a hope for such kind of diseases. There are reports that scientists could either isolate the components from the drug plant origin which inhibits the growth of concerned organism by changing in microbial physiology or by changing their metabolic products. There are certain reports in which it has been mentioned that drug plants are effective in controlling some fatal human diseases.

Swayamjot et al. (2005), studied the in-vitro cytotoxic and apoptotic activity of Triphala on cancer cell lines using Shionogi 115 (S115) and MCF-7 breast cancer cells and PC-3 and DU-145 prostate cancer cells as models. They found that acetone extract of "Triphala" was found to show significant effect on these cancer cell-lines and the effect was similar on all cancer cell lines. Khantamat et al. (2004), studied the effect of different parts of Momordica charantia against MDR which was due to over expression of 17 OK Da-p-glycoprotein (Pgp) which was responsible for less deposition of the drug in the cancerous cells could be initiated by the leaf extract of above plant against MDR human cervical carcinoma KBV1 cell (high Pgp expression). They found that the leaf extracts increased the intracellular accumulation of $\left[{ }^{3} \mathrm{H}\right]-$ Vinblastine in KB-V-1 cells. Lin et al. (1999) study the cancer chemoprevention by tea polyphenols through mitotic signal transduction blockade. They found that 
the major tea polyphenol (-)-epigallocatechin-3-gallate (EGCG) suppress extracellular signals and cell proliferation through epidermal growth factor receptor binding in human A431 epidermoid carcinoma cells; EGCG also blocks the induction of nitric oxide synthase by down-regulating lipopolysaccharide-induced activity of the transcription factor NFB in macrophages.

A Chinese drug plant, Rhus chinesis which is used as a folk medicine in china was evaluated against HIV-1 by Wang et al. (2005). They extracted the components in different solvent i.e. petroleum ether, ethyl acetate, butanol and water. They found that extract of petroleum ether could inhibit syncytium formation and HIV-1 p24 at non toxic concentration $\left(\mathrm{EC}_{50}\right.$ ) were 0.71 and $0.93 \mathrm{ig} / \mathrm{ml}$. although it was quite effective and therapeutic index (TI) WAS $100 \%$ but could not show inhibitory activity iin HIV-1 recombinant RT and entry on the host cells but the possibility are there about post steps or target by RC-1 extract may be further investigated for their future possibilities in HIV-1 infection.A screening study of organic and aqueous extracts of Southerlandia frutescens $(L$.) and Lobostemon trigonus for Anti-HIV activities was carried out by Harnett et al. (2005). They found that the Sutherlandia extracts contain inhibitory compounds active against HIV target enzymes, while aqueous Lobstemon leaf extracts contain a potent HIV-1 RT inhibitor, thus showing a potential mechanistic action of these plants in aiding HIV-positive patients. Curcumin, an extract of Turmeric, Curcuma longa L., which has been used in the treatment of arthritis, diabetes and as a anti-inflammtory agent for centuries, has been studied for anti-rheumatic activity in synovinocyte, angiogenesis inhibition in smooth muscle cells and for anticancer potential in mouse lymphoma cells in vitro and for hypoglycemic activity by oral gavage in streptozotocin (STZ) -diabetic rats in vivo alone and in combination with vanadyl ion in the form of vanadyl curcumin complex (VO $\left(\mathrm{cur}_{2}\right.$ ) by Thompson et al. (2004). They found that vanadyl curcumin complex $\left(\mathrm{VO}\left(\mathrm{cur}_{2}\right)\right.$ was more effective as an anticancer agent, more than twice effective as an anti-arthritic agent and four times effective in inhibitory smooth muscle cell proliferation, compared to curcumin alolne along with no negative symptoms during a long treatment period of one month at doses up to $2.00 \mathrm{mmol}$ $\mathrm{kg}$ day. Pyricularia oryzae mycelia, a phytopathogenic fungus responsible for rice blast, was developed for screening of antifungal and antineoplastic agents from fungus metabolites and traditional Chinese medicine wikstroemia indica by Ke Hu et al. (2000). They isolated one biscoumarin i.e. daphnoretin, one lignin i.e. nortrachelogenin, and four biflavonoids i.e. genkwanol A, wikstrol A, wikstrol B, and dephodorin B, from the roots of wikstroemia indica by bioactivity guided fractionation with the P.oryzae bioassay. They found that all the four isolated biflavonoids showed moderate activity against microtubule polymerization with $\mathrm{IC}_{50}$ values of $112 \pm 4,131 \pm 3,184 \pm 6,142 \pm 2 \mathrm{iM}$ in vitro. All the isolated compounds induced morphological deformation of P.oryzae mycelia with MMDC values of $6.8 \pm 1.3,31.3 \pm 1.8,45.8 \pm 0.5,70.1 \pm 2.4,52.3 \pm 0.9$ and $73.7 \pm 1.6 \mathrm{ìM}$ and compounds nortrachelogenin, genkwanol, wikstrol B and daphoderin B were moderetly active against HIV-1 invitro. These findings of bioactivity of all the isolated compounds support the antifungal, antimitosis and anti HIV-1 uses for W.indica roots.

Magnosalin. A neolignan isolated from Japanese Sinemedicine 'Shin-i' (flos magnoliae) has been demonstrated to inhibit the proliferation of synovial cell in the pathogenic state of RA (rheumatoid arthritis) by Kobayashi et al. (1998). In this study the inhibitory effect of magnosalin on cell proliferation were compared with those of anti-rheumatic sdrugs in RA models, MRL/1pr and CIA mice and RA patients. The effects of magnosalin on the cytokine stimulated proliferation of synovial cells in C57 BL/6J mice were also examined to investigate the mode action of magnolasin in the pathogenic state of RA. They found that 2.39-23.9 iM of magnosalin inhibited $5 \%$ fetal bovine serum (FBS)- Stimulated $\left[{ }^{3} \mathrm{H}\right]$ thymidine incorporation into the synovial cells in the MRL/1pr mice. The effect of magnosalin was greater than that of hydrocortisone, bucillamine, and magnoshinin (another comp. from shin-i) but found weaker than that of corticostrone. In case of FBS - induced thymidine incorporation into the cells of the CIA mice and RA patients, the effects were greater than those of control mice and osteoarthritis patients. The clinical efficacy of traditional anti-rheumatic herbal medicines of china on acutr and serve arthritis or immune disease was investigated by Chou and Chang, (1998). In this study, four herbal formulations i.e. (SYGTT), (SISTY), (SILAS), (MSTYGT) and one herb i.e. Triptergium willfordii (T2) were tested invotro to determine their effects on prostaglandin $\mathrm{E}_{2}\left(\mathrm{PGE}^{2}\right)$ and interleukin 2 (IL2). The peripheral blood mononuclear cells from healthy formulations and one herb in different concentration with and without mitogen stimulation. The culture supernatant were subjected to enzyme immunoassay for the measurement of PGE2 and IL2. They found that PGE2 release is inhibited by MSYGT at $500 \mathrm{ig} / \mathrm{ml}$ and by SYGTT, STSTY, STLAS at $100 \mathrm{iM}$. However, similar response was expressed by $\mathrm{T}_{2}$ at $2 \mathrm{ìg} / \mathrm{ml}$. For IL 2 inhibition, the concentrations of these herbal formulations were exceeding $100 \mathrm{ig} / \mathrm{ml}$. The anti-inflammatory property of total ethanol extract (TEE), three alkaloid fractions, and oxyacanthine isolated from Berberis vulgaris roots, a comparative study was carried out by Ivanovyska and Philopov, (1996). They found that the TEE was the most effective in a chronic inflammatory model of adjuvant 
arthritis. The anti-inflammatory and anti ulcer activity of Teucrium buxifolium was studied by Punter et al. (1997) and Teucrium buxifolium species have displayed significant antiulcer and cytoprotective activity. Inhibition of Adenovirus infection and adenain by green tea catechins was reported by Weber et al. (2003). Green tea catechins have been reported earlier to inhibit proteases involved in cancer metastasis and infection by influenza virus and HIV (Weber et al.,2003).

\section{APPLICATION OF DRUG PLANTS OTHER THAN THERAPEUTICS}

Drug plants as nutraceuticals: A large number of drug plants have been used since ancient times as good source of various components needed for good human health and can be called as functional food. These functional foods promote better health with good immunity which helps to reduce the chances of illness as well as from chronic illness. Certain ingredients which may be consider as a functional foods are dietary fibers, vitamins, minerals, oligosaccharides, essential fatty acids, lactic acid bacteria (curd), and antioxidants.

Drug plants as a major source of an antioxidant components: A large number of drug plants (different parts and their products) are being generally used in diet such as different spices, Turmeric, Coriander, Clave, Cardamom, Cinnamon, Saffron, Ginger, Onion, Garlic, and Chilies etc. since last decades a tremendous interest have been found among the scientist about possible role in prevention of human diseases generated by oxidation of different components by reactive oxygen species (ROS) and free radicals.

In biological system, oxygen give rise to large number of free radicals and other reactive species collectively called as reactive oxygen species (ROS). Another grouped reactive species are termed reactive nitrogen species (RNS). In normal condition, both remain under controlled level by antioxidant defense. But under certain adverse condition they may facilitate pro-oxidants which results oxtant stress. Under oxidative stress, cellular damage starts and degree of cellular damage will be depend on intensity of oxidative stress.

The discovery of the inhibition of the lipid per oxidation by some phenolic compounds during the late 1940's, contributed to the application of synthetic oxidation in the food industry. A large number of synthetic oxidants could be produced such as butylated hydroxyanisole (BHA), butylated hydroxytoluene (BHT), propyl gallate (PG) and others have been dominant since their introduction. But due to the side effects of these synthetic antioxidants, more concentration has been made to get natural antioxidants from the plant sources. It has been found that herbs are not only the rich source of potent antioxidants as well as retard lipid oxidative rancidity in foods (Olukemi et al., 2005; Sherwin, 1990). Medicinal plants possessing natural antioxidants polyphenolics such as anthraquinones, flavonoids, aromatic acids, and tannins have been shown to have ROS scavenging and lipid peroxidation prevention effects. (Olukemi et al., 2005; Hong et al., 1994).

Mechanism of antioxidant action: Antioxidant are compounds that help to inhibit the many oxidation reactions caused by free radicals such as singlet oxygen, superoxide, peroxyl radicals, hydroxyl radicals and peroxynitrite thereby preventing or delaying damage to the cells and tissues. their mechanism of action include scavenging reactive oxygen and nitrogen free radical species, decreasing the localised oxygen concentration thereby reducing molecular oxygen's oxidation potential, metabolizing lipid peroxides to non-radical products and chelating metal ions to prevent the generation of free radicals. In this way antioxidants limits the free radical damage from Oxidizing Low Density Lopoprotein (LDL) cholesterol, which may increase the risk of atherosclerosis, promoting platelet adhesion, which can lead to thrombosis thereby increasing the risk of heart disease or stroke, damaging the cell's DNA, which may lead to cancer, blocking the normal endothelial cell function and vasodilation in response to nitric oxide, a potential mechanism for heart disease and cancer, triggering inflammation and impairing immune function (Olukemi et al., 2005; and Lakenbrink et al., 2000).

\section{Recommendation for future planning}

Twenty first century seems to face a major global health management problem due to developing antibiotic resistance in bacterial pathogens. Since a large number of reports are regularly coming regarding appearance of newer multidrug resistant bacterial pathogens which have limited the use of cheap and old antibiotics which were quite effective earlier. In order to obtain new antimicrobial compounds specially from the plant world, it becomes an imperative to make a continuous researches in this direction. Further, the mechanism of development of resistance among the pathogens seems an important aspects and needed much attention to understand the resistance development process in order to make an effective plan. In making the future strategies to over come these problems, the molecules of antibacterial obtained from the plants should be placed in three separate groups i.e. Traditional antibiotics, Multidrug resistance inhibitors/killers and Compounds that target the virulence of the pathogens and more emphasis should be concentrated with these objectives. It is obvious that only the plant world would serve as a source of new antimicrobial compounds and resistance modifying agent in future, therefore it is an urgent need of the time to concentrate the researches in the above cited areas for 
making a successful management of health problems.

\section{REFERENCES}

Abere, T.A., Onyekweli, A.O. and Ukoh, G.C.(2007). In vitro Antimicrobial Activity of the Extract of Mitracarpus scaber Leaves Formulated as Syrup. Tropical Journal of Pharmaceutical Research, 6 (1): 679-682.

Aboaba, O.O., Smith, S.I. and Olude, F.O.(2006). Antibacterial effect of plant extract on E.coli 0157:H7. Pakistan Journal of Nutrition, 5(4): 387-390.

Abukakar, M.G., Ukwuani, A.N. and Shehu, R.A.(2008). Phytochemical screening and Antibacterial activity of Tamarindus indica pulp extract. Asian Journal of Biochemistry, 3(2): 134-138.

Agrawal, S.S., Tamrakar, B.P. and Paridhavi, M.(2005). Clinically useful herbal drugs. Ahuja publishing house, Delhi, $1^{\text {st }}$ Edn.

Al-Bayati.A Firas.(2008). Synergistic activity between Thymus vulgaricus and Pimpinella anisum essential oils and methanol extracts. Journal of Ethnopharmacology, 116: 403-406.

Ali, N.H., Uroojkazmi, S. and Faizi, S.(2007). Activity of synergistic combination Amoxy-Cassia against Salmonella. Pak. J. Pharm. Sci, 20(2): 140-145

Amalgboul, A.Z., Bashir, A.K., Farouk, A. and Salih, A.K.M.(1985). Antimicrobial activity of certain Sudanese plants used in folkloric medicines. Screening of antibacterial activity. Fitoterapia, 56: 331-337.

Anonymous (2002). Working party on herbal medicinal products. Points to consider on good agricultural and collection practice for starting materials of herbal origin. The European Agency for the Evaluation of Medicinal products. Retrieved from the webpage: http:// www.emea.europa.eu/pdfs/human/hmpc/003199en.pdf on $12 / 10 / 2009$.

Anonymous (2004a). Herbals in India: opportunities, challeng-es and initiatives by NABARD. National Bank for Agricultural and Development, India.

Anonymous, (2004b). In: Final report of research study on "Mechanism for sustainable development \& promotion of herbal \& medicinal plants in the state of Uttaranchal (India)", forwarded to SER Division, Planning Commission, Govt. of India, Parliament Street,New Delhi. Natural Resources India Foundation (NRIF), 93, GH-9, Pocket, Sunder Vihar, New Delhi - 110087.

Anonymous,(2008). Laboratory Manual for Bacterial Antimicrobial Susceptibility Testing. OIE Terrestrial Manual. Chapter 1.1.6: 56-65.

Artizzu, N., Bonsignore, L., Cottiglia, F. and Loy, G.(1995). Studies of the diuretic and antimicrobial activity of Cynodon dactylon essential oil. Fitoterapia, 66: 174-175.

Ates, D.A. and Edrogrul, O.T.(2003). Antimicrobial activities of various medicinal and commercial plant extracts. Turk $J$. Bio, 27: 157-162.

Bag, A., Bhattacharyya, S.K., Bharati, P., Pal, N.K. and Chattopadhyay, R.R.(2009). Evaluation of antibacterial properties of Chebulic myrobalan (fruit of Terminalia chebula Retz.) extracts against methicillin resistant Staphylococcus aureus and trimethoprim-sulphamethoxazole resistant uropathogenic Escherichia coli. African Journal of Plant Science, 3 (2): 025-029.
Berry J.P., McFerren M.A. and Rodriguez E.(1995). Zoopharmacognosy: A "biorational" strategy for phytochemical prospecting. In: Gustine DL, Flores H. (Eds.), Phytochemicals and Health, ASPP, Rockville. 165178.

Belboukhari, N. and Cheriti., A.(2008). Ethnomedical and Antimicrobial studies of Launeae Naudiculus. Electronic Journal of Environmental, A gricultural and Food Chemistry, 7 (14): 2749-2753.

Bhattacharjee, I., Soroj, K.C., Soumendranath, C. and Goutam, C.(2006). Antimicrobial potentiality of Argemone mexicana solvent extracts against some pathogenic bacteria. Mem Inst Oswaldo Cruz, Rio de Janerio, 101(6): 645-648.

Bhushan, B., Prakash, I. and Abhay, F.(2008). Evaluation of antimicrobial activity of medicinal plant Jatropha padagrica (hook). Roumanian Biotechnological letters, 13(5): 38733877.

Bonjar, S.(2004). Evaluation of antibacterial properties of some medicinal plants used in Iran. Journal of Ethnopharmacology, 94: 301-305.

Butani, K.K., Taggi, D.K., Anand, B.S., Kapil, R.S., Pushpangadan, P. and Rajsekhran, S.(1994). A process for the preparation of a glycolipid fraction from Trichopus zeylanicus possessing adaptogenic activity. Patent application No. 88/Del/94.

Butcher, S.P.(2003). Target discovery and validation in the postgenomic era. Neurochem Res, 28: 367-371.

Chou, C.T. and Chang, S.C.(1998). The inhibitory effect of common traditional anti-rheumatic herb formulas on prostaglandin $\mathrm{E}$ and interleukin 2 in vitro: a comparative study with Tripterygium wilfordii. journal of Etnopharmacology, 62: 167-171.

Cos, P., Vlietinck, A.J., Berghe, D.V. and Maes, L.(2006). Antiinfective potential of natural products: How to develop a stronger invitro 'proof-of-concept'. Journal of Ethnopharmacology, 106: 290-302.

Cowan, M.M. (1999). Plants products as Antimicrobial agents. 565-582.

Cox, P. A.(1990). Ciba Foundation Symposium 154, Chichester, John Wiley \& Sons. 40.

Cox, P.A., and Balick, M.J. (1994). The ethnobotanical approach to drug discovery. Scientific American, 82-87.

Cox, P.A.(1994). The ethnobotanical approach to drug discovery: strengths and limitations. In: Ethnobotany and the Search for NewDrugs. Ciba Foundation Symposium 185. John Wiley \& Sons, Chichester. 25-41.

Czech, E., Wolfgang, K. and Brigitte, K.(2000). Microbiological status of commercially available Medicinal Herbal Drugs- A screening study. Planta Med, 67 (2001): 263-269.

Dubey, N.K., Kumar, A., Singh, P. and Shukla, R.(2008). Microbial contamination of raw materials: A major reason for the decline of India's share in the global market. Current Science, 95(6): 717-718.

Eisenberg, D.M., Kesseler, R.C., Foster, C., Norlock, F.E., Calkins, D.R. and Delbanco, T.L.(1993). Unconventional medicine in the United States: prevalence, costs and patterns of use. N. Engl. J. Med, 328: 246-252.

Edrogrul, O.T.(2002). Antibacterial activities of some plant extracts used in folk medicine. Pharmaceutical Biol, 40: 269-273. 
Ernst, E.(1998). Harmless herbs? A review of the recent literature. Am J Med, 104: 170-178.

Ekka, N.R., Namdeo, K.P. and Samal, P.K.(2008): Standardization strategies for herbal drugs- An overview. Research J. Pharm. and Tech, 1(4): 310-312.

Farnsworth, N.R. and Bingel, A.S.(1977). Problems and prospects of discovering new drugs from higher plants by pharmacological screening. In. Wagner H, Wolff P. (Eds.), New Natural Products and Plant Drugs with Pharmacological, Biological or Therapeutical Activity. Springer, Berlin, Germany. 1-22.

Farnsworth, N.R.(1993). Biological approaches to the screening and evaluation of natural products. In. Rasoanaivo P, Ratsimamanga-Urverg S. (Eds.), Biological Evaluation of Plants with Reference to the Malagasy Flora, Monograph from the IFS-NAPRECA Workshop on Bioassays. Madagascar. 35- 43.

Farnsworth, N.R.(1996). Biological and phytochemical screening of plants. J Pharm Sci, 55: 225-276.

Ghalem, B.R. and Benali, M.(2008). Antibacterial activity of leaf essential oils of Eucalyptus globules and Eucalyptus camadulensis. African Journal of Pharmacy and Pharmacology, 2(10): 211-215.

Hamburger, M. and Hostettmann, K.(1991). Bioactivity in plants: The link between phytochemistry and medicine. Phytochem, 30: 3864-3874.

Handa, S.S.(1998). Indian Herbal Pharmacopoeia Vol. I \& II, IDMA, Mumbai.

Handa, S.S.(1999). Indian Herbal Pharmacopoeia Vol. I \& II, IDMA, Mumbai.

Harnett, S.M., Oostuizen, V. and van de Vanter, M.(2005). AntiHIV activities of organic and aqueous extracts of Sutherlandia frutescens and Lobostemon trigonus. Journal of Ethnopharmacology, 96: 113-119.

Howaida, F., Abdelrahman, Skaug, N., Georga, W., Francis, Dr. ing. and Fil, dr.(2002). In vitro antimicrobial effects of crude miswak extracts on oral pathogens. Saudi Dental Journal; 14(1):

Hong, C.Y., Wang, P.O., Lo, C.P. and Hsu, F.L.(1994). Effect of flavanoids-3-ol tannins purified from Camellia sinensis on lipid peroxidation of rat heart mitocondria. Am.J.Chin. Med, 22: 285-292.

Ikram, M. and Inamul, H.(1984). Screening of medicinal plants for antimicrobial activities. Fitoterapia, 55: 62-64.

Ivanovska, N. and Philipov, S.(1996). Study on the antiinflammatory action of Berberis vulgaris root extract, alkaloid fractions and pure alkaloids. Int. J. Immunopharmac, 18(10): 553-561.

Izzo, A.A., Carlo, Di., Biscardi, G., Fusco, D., Mascolo, R., Borreli, N., Capasso, F., Fasulo, F. and Autore, M.P.(1995). Biological screening of Italian medicinal plants for antibacterial activity. Phytother Res, 9: 281-286.

Jeon, J-H., Song, H-Y., Kim, M-G. and Lee, H-S.(2009). Antocoagulent properties of Alizarin and its Derivatives of Cassia obtusifolia. J. Korean Soc Appl. Biol. Chem, 52(2): 163-167.

Johnston, P.A.(2002). Cellular platforms for HTS: Three case studies. Drug Discov Today, 7: 353-363.

Kandhansamy, M. and Anurachalam, K.D. (2008). Efficacy of Typhonium trilobatum (L.) schott extracts on pathogenic bacteria. Electronic Journal of Natural Substance, 3: 1-7.

Kamboj, V.P.(2000). Herbal Medicine. Current Science, 78(1): 35-39.

Kaul, M.K., Sharma, P.K. and Singh, V.(1989). Ethnobotanical studies in northwest and trans-Himalaya VI. contribution to the ethnobotany of Basohli-Bani region, J \& K. Bulletin of Botanical Survey of India, 31: 89-94.

Ke Hu., Kobayashi, H., Dong, A., Iwasski, S. and Yao, X.(2000). Antifungal, Antimitotic and Anti-HIV-1 Agents from the roots of Wikstroemia indica. Planta Med, 66.

Khantamat, O., Limtrakul, P. and Pintha, K.(2004). Inhibition of P-glycoprotein activity and reversal of cancer multidrug resistance by Momordica charantia extract. Cancer Chemother Pharmacol, 54: 525-530.

Kinghorn, A.D.(1994). The discovery of drugs from higher plants. Biotechnology, 26: 81-108

Kitula, R.A.(2007). Use of medicinal plants for human health in Udzungwa Mountains Forests: a case study of New Dabaga Ulongambi Forest Reserve, Tanzania. Journal of Ethnobiology and Ethnomedicine, 3:7 doi:10.1186/17464269-3-7.

Kobayashi, S., Kobayashi, H., Komura, I., and Kimura, M.(1998). Inhibitory effects of anti-rheumatic drugs containing magnosalin, a compound from 'Shin-I' (Flos magnolia), on the proliferation of synovial cells in rheumatoid arthritis models. Immunopharmacology, 39: 139147.

Kubo, L., Muroi, H. and Himejima, M.(1993). Structureantibacterial activity relationships of anacardic acids. J Agri Food Chem, 41: 1016-1019.

Kursar, T.A., Capson, T.L., Coley, P.D., Corley, D.G., Gupta, M.B., Harrison, L.A., Ortega- Barría, E. and Windsor, D.M.,(1999). Ecologically guided bioprospecting in Panama. Pharmaceutical Biol, 37: S114-S126.

Lakenbrink, C., Lapczynski, S., Maiwald, B., and Engelhardt, U.H.(2000). Flavanoids and other polyphenols in consumer brews of Tea and other caffeinated beverages. J.Agric Food Chem, 48: 2848-2852.

Lin, J.K., Liang, Y.C. and Lin-Shiau, S.Y.(1999). Cancer chemprevention by tea polyphenols through mitotic signal transduction blockade- The role of DNA base damage. Biochaemical Pharmacology, 58(6): 911-915.

Mendonca-Filho, R.R.(2006). Bioactive Phytocompounds: New Approaches in the Phytosciences. In: Ahmad I, Aqil F, Owais M. (eds.), Modern Phytomedicine: Turning Medicinal Plants into Drugs. WILEY-VCH Verlag GmbH \& Co. KGaA, Weinheim. 1-24.

Min, B. R., Pinchak, W. E., Merkel, R., Walker, S., Tomita, G. and Anderson, R. C. (2008) Comparative antimicrobial activity of tannin extracts from perennial plants on mastitis pathogens. Scientific Research and Essays, 3 (2): 066-073

Moon, J.Y., Kim, H., Cho, M., Chang, W.Y., Kim, C.T. and Cho, S.K.(2009). Induction of Apoptosis in SNU-16 Human Gastric Cancer Cells by the Chloroform Fraction of an extract of Danyuja (Citrus grandis) Leaves. J. Korean Soc. Appl. Biol. Chem, 52(2): 168-175.

Moore, K. and Rees, S.(2001). Cell-based versus isolated target screening: How lucky do you feel? J Biomol Screen, 6, 69-74. 
Navarro, V., Villarreal, M.L., Rojas, G. and Lozoya, X.(1996). Antimicrobial evaluation of some plants used in Mexican traditional medicine for the treatment of infectious diseases. J. Ethanopharmacol, 53, 143-147.

Neto, L.L.S., Toledo, M.A.V., de Souza, P.M. and de Souza, G.A.(2006). The Use of Herbal Medicine in Alzheimer's Disease-A Systematic Review. Ecam, 3(4): 441-445

Nogueira, J.C.R., Margareth de Fátima Melo Diniz and Lima, E.O.(2008). In vitro antimicrobial activity of plants in Acute Otitis Externa. Rev Bras Otorrinolaringol, 74(1): 118-24.

Olukemi, O.A., Olukemi, I.O., Oluwatoyin, S.M., Austin, A.O., Mansurat, L.B. and Olufunmilola, T.I.(2005). Antioxidant activity of Nigerian dietary spices. Electronic Journal of Environmental, Agricultural and Food Chemistry, 4(6):1086-1093.

Patwardhan, B., Vaidya, A.D.B. and Chorghade, M.(2004). Ayurveda and natural products drug discovery. Curr. Sci, 86: 789-799.

Phillipson, J.D. and Anderson, L.A.(1989). Ethnopharmacology and Western medicine. $J$ Ethnopharmacol, 25: 61-72.

Prance, G.T.(1994). Introduction, Ciba Foundation Symposium. In: Ethnobotany and the Search for NewDrugs. Ciba Foundation Symposium 185. JohnWiley \& Sons, Chichester, 1-3.

Prasad, R. and Patnaik, S.(1998). Conservation Assessment and Management Planning (CAMP) workshop for Non Timber Forest products in MP. CAMP workshop briefing book. IIFM, Bhopal (MP), India.

Prasad, G., Sharma, N. and Gupta, K.K.(2002a). Quantitative enumeration of microflora of certain herbal Ayurvedic drugs during storage. Hamdard Medicus, XLV (I): 73-77.

Prasad, G., Tyagi, R., Bhardwaj, D.D. and Gupta, K.K. (2002b). Screening of antimicrobial potential of certain drug plants for enhancement of their therapeutic spectrum in vitro. Hamdard Medicus, XLV (2): 77-81.

Prasad, G., Matiyan, P., Gupta, K.K., Sharma, P. and Prashant.(2003). Microbial flora and drug efficacy related with enhancement of therapeutic spectrum of three ingredients of triphala drug during storage. Hamdard Medicus, XLVI (4): 82-87.

Prasad, G., Sharma, P., Gupta, K.K. and Chopra, A.K.(2007). Effect of Microbial contaminants of Triphala Drug efficacy during storage and enhancement of therapeutic spectrum of the drug In Vitro. Hamdard Medicus, 50 (3): 55-62.

Prasad, G., Singh, P., Sharma, M. and Gupta, K.K. (2006). Antimicrobial potency of three fruit drug and formulated triphala drug against certain bacterial disease associated with urinary tract infections in vitro. Hamdard Medicus, XLV (3): 34-40.

Prasad, G., Gupta, K.K., kumara, P. and Chopra, A.k. (2007). Evaluation of therapeutic potential of some drug plant by drug efficacy test in vitro. Hamdard Medicus, XLV (2): 7882.

Punter, B.F., Peinado,I.I. and Villar de Frasno, A.M.(1997). Anti-inflammatory and anti ulcer activity of Teucrium buxifolium. Journal of Ethnopharmacology, 55: 93-98.

Pushpangadan, P., Rajasekhran, S., Kumar, R., Jawahar, C.R., Velayudhan Nair, V., Lakshmi, N. and Sarad Amma, L.(1988). Arogyapacha (Trichopus zeylanicus) — the Ginsneng of Kani tribes of Agasthyar Hills (Kerala) for evergreen health and vitality. Ancient Science of Life, 7: 13-16.

Pushpangadan, P., Rajsekhran, S. and George, V.(1996). A process of preparation of novel immunoenhancing antifatigue, anti-stress and hepato-protective herbal drug. Patent application number 959/MAS/96 dated June 4.

Qaas, F. and Schiele, E. (2001). Einfluss der Energiekosten auf die Rentabilität im Trocknungsbetrieb. Zeitschrift für Arzneiund Gewürzplanzen, 6 (3): 144-145.

Raina, M.K.(1996): Aloe in supplement to cultivation and utilization of medicinal Plants, eds. By Handa, S.S., and Kaul, M.K., RRL (CSIR), Jammu-Tawi. 313-322.

Reddy,P.S., Jamil, K., Madhusudan, P., et al.(2001). Antibacterial activity of isolates from Piper longum and Taxus baccata. Pharmaceutical Biol, 39: 236-238.

Remirez, D.C.(2006). Update in Pre-Clinical Regulatory Requirements for Phytomedicines in Latin America. J Compl Int Med, 3(1): 3.

Roman, M.(2001). The benefits and pitfalls of standardizing botanicals extracts. Natural Products insider. (http:// www.naturalproductsinsider.com/articles/473/ 473_141labin2.html).

Samy, R.P., Pushpara, P.N., and Gopalakrishnakone, P.(2008).A compilation of bioactive compounds from Ayurveda. Bioinformation, 3(3): 100-110.

Satyavati, G.V., Raina, M.K., and Sharma, M.(1976). Medicinal Plants of India, ICMR, New Delhi.

Seher, G., Dilek, T.B. and Nazmi, G.(2006). Antimicrobial activities and some fatty acids of Turmeric, Ginger root and Linseed used in the treatment of infectious diseases. World Journal of Agricultural Sciences, 2(4): 439-442.

Shah, M.B. and Chauhan, G.(1996). In: supplement to cultivation and utilization of Medicinal Plants, eds. By Handa, S.S., and Kaul, M.K., RRL (CSIR) Jammu-Tawi. 53-96.

Shapoval, E.E.S., Silveria, S.M., Miranda, M.L., Alice, C.B. and Henriques, A.T.(1994). Evaluation of some pharmacological activities of Eugenia uniflora. J Ethnopharmacol, 44: 136-142.

Shrikumar, S. and Ravi, T.K.(2007). Approaches towards development and promotion of herbal drugs. PHCOG REV: short review, 1(1): 180-184.

Sherwin, E.R.(1990). Antioxidants. In: Food additives (A. L. Branen, P.M. Davidson, S. Salminen ed.), Marcek Dekker Inc, New York, USA. 139-193.

Singh, K.N. and Lal, B.(2008). Ethnomedicines used against four common ailments by the tribal communities of LahaulSpiti in western Himalaya. Journal of Ethnopharmacology, 115: 147-159.

Sousa, M., Pinheiro,C., Matos, M.E.O., Matos, F.J., Lacerda, M.I. and Craveiro, A.A.(1991). Conatituintes Quimicod de Plantas Medicinais Brasileiras, Universidade. Federal do Ceara Fortaleza. 385-388.

Srivastava, V.k. and Singh, B.M.(1996). Indian aloe in supplement to cultivation and utilization of Medicinal Plants, (Eds.), By Handa, S.S., and Kaul, M.K., RRL (CSIR), Jammu-Tawi. 323-332.

Subramanian, V., Gautam, V., Raman, R.M.V., Prahalathan, S. and Ashish, K.(2003). T.C Forward, in Road Beyond Boundaries ( The Case of Selected Indian Healthcare 
Systems), Export- Import Bank of India, Mumbai. 7-9. Subramoniam, A., Evans, D.A., Valsaraj, R., Rajsekhran, S. and Pushpangadan, P.(1999). Inhibition of antigen-induced degranulation of sensitized mast cells by Trichopus zeylanicus in mice and rats. Journal of Ethnopharmacology, 68: $137-143$

Subramoniam, A., Madhavachandran, V., Rajsekhran, S. and Pushpangadan, P.(1997). Aphrodisiac property of Trichopus zeylanicus extract in male mice. Journal of Ethnopharmacology, 57: 21-27.

Swayamjot, K., Husheem, M., Saroj, A., Pirkko, L.H. and Subodh, K.(2005). The in-vitro cytotoxic and apoptotic activity of Triphala- an Indian Herbal Drug. Journal of Ethnopharmacology, 97: 15-20.

Taylor, J.L.S., Rabe, T., McGaw, L.J., Jäger, A.K. and van Staden, J.(2001). Towards the scientific validation of traditional medicinal plants. Plant Growth Regulation, 34: 23-37.

Thompson, K.H., Bohmerle, K., Poloshchuk, E., Martins, C., Toleikis, P., Tse, J., Yuen, V., McNeill, J.H. and Orvig, C.(2004). Complementry inhibition of synoviocyte, smooth muscle cell or mouse lymphoma cell proliferation by a vanadyl curcumin complex compared to curcumin alone. Journal of Inorganic Biochemistry, 98: 2063-2070.

Umamaheswari, A., Shreevidya, R. and Nuni, A.(2008). In vitro Antibacterial Activity of Bougainvillea spectabilis Leaves Extracts. Advances in Biological Research, 2 (1-2): 01-05.

Vaidya, A.D.B. and Devasagayam, P.A.(2007). Current Status of Herbal Drugs in India: An Overview. Recent Advances in Indian Herbal Drug Research. J.Clin. Biochem. Nutr, 41: 1-11.

Vaidya, A.D.B.(1992): Some principles and practices of Ayurveda in selected Medicinal Plants of India, Bhavan's SPARC, Mumbai. 365-370.
Veale, D.J.H., Furman, K.I., and Oliver, D.W.(1992). South African traditional herbal medicines used during pregnancy and child birth. J. Ethnopharmacol, 36: 185-191.

Verpoorte, R.(2000). Pharmacognosy in the new millennium: lead finding and biotechnology. J Pharm Pharmacol, 52: 253-262.

Vlietinck, A.J., and Vanden Berghe, D.A.(1991). Can ethnopharmacology contribute to the development of antiviral drugs? J Ethnopharmacol, 32: 141-153.

Walker, R.D.(2000): Antibacterial susceptibility testing and interpretation of results. In: Antimicrobial Therapy in Veterinary Medicine, Prescott, J.F., Baggot, J.D., Walker, R.D., eds. Ames, IA, Iowa State University Press, 12-26.

Wang, R.R., Gu, Q., Yang, L.M., Chen, J.J, Li, S.Y. and Zheng, Y.T.(2005). Anti-HIV-1 activities of extracts from the medicinal plant Rhus chinensis. Journal of Ethnopharmacology, 105(1-2): 269-273.

Weber, J.M., Umunyana, A.R., Imbeault, L. and Sircar, S.(2003). Inhibition of adenovirus infection and adenain by green tea catechins. Antiviral Research, 58: 167-173.

WHO.(1978). The Promotion and Development of Traditional Medicine. WHO Technical Report Series, No. 622:8, Geneva, Switzerland.

WHO.(2000). General guidelines for methodologies on research and evaluation of traditional medicine. World Health Organization, Geneva, 71.

WHO.(2003). WHO guidelines on good agricultural and collection practices (GACP) for medicinal plants. World Health Organization, Geneva, 1-72.

Yogeeswaran, G.(2003). Bio-entrepreneurship in tradition driven herbal technology. Advanced Biotech, 2: 22-24. 